\section{Lamarck: Dood maar nie begrawe}

J.N. Coetzee, Mediese Navorsingsraad: Eenheid vir Mikrobiese Genetika, Departement Geneeskundige Mikrobiologie, Universiteit van Pretoria

Jean Baptiste Pierre Antoine de Monet Chevalier de Lamarck, lid van L'Academie Francaise, is op 18 Desember 1829 oorlede. Lamarck, 'n man so woelig en haaks soos die onstuimige tydsomstandighede waarin hy gewerk het, was eers 'n leerlingpriester en toe 'n ruk lank offisier in die Franse weermag voordat hy begin het met geneeskundige studies in Parys. $\mathrm{Na}$ hy hierdie studies gestaak het, het hy naam gemaak as plantkundige. Later, as professor in dierkunde, was hy betrokke by die vestiging van die studie van ongewerwelde diere as 'n vertakking van die Dierkunde. Hy was die skepper van die woord biologie. Hy het sy wye ervaring in 'n geheelbeeld van die ewolusie saamgevat in die Philosophie Zoologique wat in 1809 , die geboortejaar van Charles Darwin, verskyn het. 1,2

Lamarck was skerpsinnig genoeg om die nut van 'n teorie te besef wat sowel die verskeidenheid van spesies as die onomstootlike bewyse van ewolusionêre prosesse wat in rotse vasgelê is, kon verduidelik. Dié twee feite kon gesamentlik verklaar word deur te aanvaar dat eienskappe wat eers verwerf is, wel oorerflik mag word. Hierdie denke was nie eie aan Lamarck nie en hy het dit self nie as sentraal in sy werk beskou nie - selfs Darwin het 'n dergelike mening gehuldig. Daar word nou besef dat die proses van ewolusie deur middel van natuurlike seleksie voortgaan ongeag die presiese wyse van oorerwing, maar die oorerflikheid van verworwe eienskappe het as klad aan niemand anders se naam as dié van Lamarck bly kleef nie. ${ }^{3,4}$

Soos die gewoonte was (en is), het die Franse Akademie na sy dood 'n gesaghebbende persoon benoem om 'n lofspraak oor Lamarck te uiter. Aan Georges Cuvier, 'n invloedryke bioloog, is hierdie opdrag gegee. Hy het die voorreg misbruik en die lofrede, wat in November 1832 voor die Akademie deur iemand anders gelees is, gebruik om 'n bitsige, venynige aanval op die gestorwene se siening oor ewolusie te loods. Lamarck se reputasie het nooit van hierdie aanslag herstel nie. ${ }^{1}$

Alhoewel Darwin bewys daarvan gelewer het dat natuurlike seleksie 'n oorwegende rol in ewolusie speel, kon die kennis wat beskikbaar was teen die tweede helfte van die $19 \mathrm{e}$ eeu, nie 'n greintjie Lamarckiaanse oorerwing as 'n toevoegsel tot Darwinisme uitsluit nie. Die huidige behoudendheid het egter sy oorsprong nie soseer in Darwin nie, maar dit het ont- staan toe die Duitser August Weismann ${ }^{3,5}$ gedurende 1885 sy stelling van die kontinuïteit van die kiemlyn verkondig het en só die neo-Darwinistiewe denke ingelei het. Volgens hom sou daar 'n ondeurdringbare versperring tussen kiemselle (ova, spermatosoë) en die res van die liggaam (soma) bestaan. Hierdie grens sou dan verhoed dat mutasies in somatiese selle toegang tot die kiemlyn verkry en gevolglik nooit in die nageslag verskyn nie. Enige geneties bepaalde verandering wat in die nageslag opduik, moes eksklusief in gene van kiemlynselle ontstaan het. $\mathrm{Na}$ sy mening kon die fenotipe die genotipe alleenlik beïnvloed deurdat meer geskikte individue groter vermoëns tot voortplanting kon openbaar. Weismann se teorie was (en is) wyd aanvaar. Die finale nekslag vir Lamarckisme het met die wisseling van die eeu gekom met die herontdekking van Mendelisme, wat 'n meganisme vir die ontstaan van variasie en hoe dit uitgeken kon word, bevat het. Die huidige neodarwinistiese siening oor ewolusie is dat dit deur seleksie van die genotipe met die grootste oorlewingswaarde geskied. Onder bakterieë met hul kort generasietye en groot bevolkings is daar blykbaar voldoende heersende versamelings mutantfenotipes om enige druksituasie die hoof te bied. In die geval van hoër selle verleen die seksuele meganisme die geleentheid om variasie in die heterosigotiese toestand vir periodieke toetse in homosigotiese gewaad te versteek. Nuwe DNA-kombinasies ontstaan gedurende meiotiese oorkruisings.

Lamarck het wel dissipels gehad, maar dié se optrede het gewoonlik net daartoe bygedra om hom (en sy beweerde stellings) in verdere onguns te bring. ' Vername volgeling was die Rus Lysenko. ${ }^{6} \mathrm{Hy}$ was 'n genetikus wie se persoonlikheid die Kremlinleiers geboei het amper soos dié van Rasputin die Tsarina voor die Russiese revolusie bekoor het. Lysenko se landboupogings was verantwoordelik vir die herhaalde mislukkings van Russiese graanoeste, wat selfs vandag nog tot Rusland se afhanklikheid van VSAgraan bydra. 'n Ander dissipel was die Weense dierkundige Paul Kammerer. Beskuldigings dat hy eksperimentele resultate vervals het om hulle beter met Lamarck se stellings te laat strook, het in 1926 tot sy selfmoord gelei. ${ }^{7}$ Nog 'n soort dissipel was die Oxfordse fisiese chemikus sir Cyril Hinshelwood, wie se eksperimentele bevindings (en afleidings) betreffende oorerflike ,,aanpassings" van bakterieë as 'n verleentheid vir die Britse Genetika beskou en liggies opsy gestoot is. ${ }^{8}$ Gevolglik word dit tans glad nie as lofwaardig beskou indien daar in 'n genetikus se werk, of uitsprake, selfs 'n sweempie Lamarckisme te bespeur is nie, en is neerhalende uitsprake soos dié van die Nobelpryswenner Salvadore Luria ${ }^{9}$ dat die Bakteriologie die laaste vesting van Lamarckisme is, algemeen.

Maar hoe staan sake vandag? Reeds in 1928 het die skaam Engelsman Fred Griffith die verskynsel van 
transformasie in pneumokokke gedemonstreer. ${ }^{10} \mathrm{Dit}$ is in 1952 gevolg deur Joshua Lederberg en sy student Norton Zinder se ontdekking van bakteriofaag-bemiddelde transduksie. ${ }^{11}$ Gedurende die laat vyftigerjare is plasmied-oordrag tussen bakterieë in Japan ontdek. ${ }^{12,13,14}$ In al hierdie verskynsels neem bakterieë genetiese materiaal van hul omgewings op, vestig dit en dra die nuwe genotipe getrou aan afstammelinge oor. Alhoewel hierdie meganismes van werwing van genetiese materiaal seer sekerlik verskil van hoe Lamarck dit sou voorgestel het, toon almal tóg die oorerwing van verworwe kenmerke. Die rol wat hierdie prosesse, asook inlasreekse en transposons ${ }^{13,15,16,17,40}$ met variasie, in bakterieë speel is 'n voldonge feit en hul belang by die ewolusie van mikroörganismes word algemeen aanvaar. ${ }^{13}, 15,18,19$

Ook kan kernsure in selle (insek, plant, soogdier) beland deur middel van viruse wat dit van 'n vorige gasheer oordra. Hier speel die retrovirusse moontlik 'n belangrikke rol. Hierdie virusse beskik oor trutranskriptases wat RNA, afkomstig van een sel, in ooreenstemmende DNA kan omskep as voorbereiding vir laasgenoemde se moontlike inlywing in die chromosoom van 'n tweede sel. Daar is nou glad xenotrofiese virusse bekend ${ }^{20}$ wat as oordraagbare virusse in een spesie ' $n$ bestaan voer, maar in 'n ander spesie as mendeliese gene hul teenwoordigheid openbaar. Bewyse is gelewer 21,22 dat die spoed waarteen mutasies binne strukturele gene van diere versamel, nie tred hou met die spoed van anatomiese ewolusie nie. Derhalwe is daar beweer dat organismes se ewolusie beïnvloed word deur wysigings van die beheer oor gene en nie soseer deur veranderings aan strukturele gene nie. ${ }^{13}$ Daar is voorgestel dat hierdie wysigings in die oorspronklike DNA teweeg gebring mag word deur virusse wat kernsure tussen selle oordra. ${ }^{23,}{ }^{24}$ Dit word as 'n horisontale transmissie van gene beskou wat die reëls van die klassieke Mendelisme ontwyk. ${ }^{25} \mathrm{Al}$ hierdie prosesse grens aan Lamarckisme. Deesdae is daar ook baie volgelinge van 'n teorie dat mitochondria en dergelike noodsaaklike organelle van eukariotiese selle die afstammelinge van simbiotiese mikroörganismes (prokariote) is, wat ver terug in die verlede primitiewe selle binnegedring het: ${ }^{26,38}$ weer 'n voorbeeld van Lamarckisme.

Die besef dat ekstrakernorganelle op sigself 'n genetiese integriteit besit en oor 'n ander wyse van oorerflikheid beskik as chromosome van die kern, het aanleiding tot die snel ontwikkelende terrein van ekstrachromosomale of nie-mendeliese erflikheid gegee. ${ }^{12}, 19,37$ Baie werk word veral op die gebied van die oorerflikheid van aansteeklike agense in diere en insekte gedoen - die sogenaamde vertikale transmissie. ${ }^{25,}{ }^{27}$ Hoewel neonatale besmetting van 'n baba deur 'n ouer as ' $n$ voorbeeld van vertikale besmetting beskou word, trek die meer subtiele wyse van vertikale oordrag - infeksie van die fetus of transmissie van 'n aansteeklike agens d.m.v. die kiemlyn as sulks ${ }^{28}$ - meer aandag. Weer grens hierdie prosesse aan Lamarckisme.

Die nuutste kampvegter vir Lamarck is ' $n$ jong
Australiese immunoloog Edward Steele. ${ }^{29}$ Kortliks: hy en ' $n$ medewerker ${ }^{30},{ }^{31}$ het normale, pasgebore mannetjiemuise verdraagsaam teenoor ' $n$ bepaalde, vreemde weefselverenigbaarheidsantigeen van 'n ander ras gemaak deur die muise herhaaldelik met massas limfoïedselle (wat die betrokke vreemde antigeen op hul oppervlakke dra), en afkomstig van die laasgenoemde ras, in te spuit. Die verdraagsame mannetjies is toe met normale wyfies gepaar. Daar is bevind dat heelwat van die muise van hierdie werpsels verdraagsaam is teenoor dieselfde weefselantigeen as dié waarop die ouerlike mannetjies nie reageer het nie. Hierdie werk, waarvan die resultate in 1980 en vroeg 1981 gepubliseer is, het groot opspraak in vooraanstaande vakjoernale gemaak ${ }^{5,32,33,34}$ en selfs kritici was dit daaroor eens dat die eksperimente briljant beplan is. ${ }^{35}$ Wat presies deur die afstammelingsmuise geërf is en hoe verdraagsaamheid bemiddel is, is nie 'n uitgemaakte saak nie.' $32,33,36$ Een verklaring lui dat RNA uit selle van die betrokke geweldig uitgesette limfö̈edklone van die verdraagsame ouerlike mannetjies ontsnap het. Hierdie RNA het (op sigself of deur bemiddeling van retrovirusse) die kiemlynselle (spermatosoë) van die mannetjies bereik (Weismannversperring en al!), is dáár met behulp van 'n tru-transkriptase in die ooreenstemmende DNA omskep, en toe in die genoom van die spermatosoë (op die regte plek!) ingelyf. Hierdie ouerlike saad was toe vir die oorerflikheid van die spesifieke verdraagsaamheid verantwoordelik. Pure Lamarckisme! Met groot belangstelling is daar op eksperimentele bevestiging deur werkers van onafhanklike laboratoriums gewag. Dit het 'n ruk later verskyn in publikasies deur 'n span immunoloë 35,39 wie se eksperimentele bevindings nie met dié van Steele geklop het nie. Die doyen van Britse immunoloë, sir Peter Medawar, was 'n lid van hierdie span. Spanlede kwyt hulle ook onder meer van die volgende wysheid: nog nooit is 'n eksperiment ter stawing van oorerflikheid van verworwe eienskappe gedoen wat nie gefalsifieer kon word nie. Daar rus die saak nou.

Ek het probeer aandui dat die verskansing waaragter kiemlynselle hulself van die soma verberg, bedreig word. 'n Verskansing dien 'n doel. Dit is só dat daar gedugte weerstand teen die omskepping van alle somatiese veranderings in genetiese wysigings moet wees. Dit is om te verhoed dat 'n organisme oorreageer op veranderings in die omgewing en om 'n mate van stabiliteit te handhaaf. Tóg, omrede van die belang van terugvoermeganismes in die Biologie, is dit te betwyfel of die Weismannversperring volkome lekvry is, of behoort te wees. Daar is voldoende ruimte in die Biologie om Darwin en Mendel en Lamarck te akkommodeer.

\section{VERWYSINGS}

1. Cannon, H.G. (1959). Lamarck and modern genetics (Manchester University Press).

2. Barthélemy-Madaule, M. (1979). Lamarck ou le Mythe du Précurseur (Paris).

3. News and Views. (1981). Too soon for the rehabilitation of Lamarck, Nature, 289, 631. 
4. News and Views. (1981). How true is the theory of evolution?, Nature, 290, 75-76.

5. Lewin, R. (1981). Lamarck will not lie down. Science, 213, 316-321.

6. Medvedev, Z.A. (1969). The rise and fall of T.D. Lysenko (New York).

7. Koestler, A. (1971). The case of the midwife toad (Hutchinson, London).

8. Dean, A.C.R. \& Hinshelwood, C. (1957). In Ciba Foundation Symposium on Drug Resistance in Micro-organisms, Wolstenholme, G.E.W. \& O'Connor, C.M. eds. (J. \& A. Churchill Ltd., London) pp. 4-29.

9. Luria, S.E. (1947). Recent advances in bacterial genetics, Bacteriological Reviews, 11, 1-40.

10. Downie, A.W. (1972). Pneumococcal transformation-a backward view, Journal of General Microbiology, 73, 1-11.

11. Zinder, N.D. \& Lederberg, J. (1952). Genetic exchange in Salmonella, Journal of Bacteriology, 64, 679-699.

12. Schwesinger, M.D. (1977). Additive recombination in bacteria, Bacteriological Reviews, 41, 872-902.

13. Reanney, D. (1976). Extrachromosomal elements as possible agents of adaptation and development, Bacteriological Reviews, 40, 552-590.

14. Watanabe, T. (1963). Infectious heredity of multiple drug resistance in bacteria, Bacteriological Reviews, 27, 87-115.

15. Campbell, A. (1981). Evolutionary significance of accessory DNA elements in bacteria, Annual Review of Microbiology, $35,55-83$.

16. News and Views. (1981). Transposable elements and proviruses, Nature, 292, 800-801.

17. News and Views. (1980). Movable genes, Nature, 287, 188-189.

18. Anderson, E.S. (1966). Possible importance of transfer factors in bacterial evolution, Nature. 209. 637-638.

19. Novick, R.P. (1969). Extrachromosomal inheritance in bacteria, Bacteriological Reviews, 33, 210-235.

20. Weiss, R.A. (1975). In Antiviral Mechanisms: Perspectives in Virology IX, Pollard, Morris, ed. (Academic press, New York) pp. 165-205.

21. Wilson, A.C., Maxson, L.R. \& Sarich, V.M. (1974). Two types of molecular evolution. Evidence from studies of interspecific hybridization, Proceedings of the National Academy of Science, USA, 71, 2843-2847.

22. King, M.-C. \& Wilson, A.C. (1975). Evolution at two levels in humans and chimpanzees, Sciences, 188, 107-116.
23. Anderson, N.G. (1970). Evolutionary significance of virus infection, Nature, 227, 1346-1347.

24. Levin, R. (1981). Do jumping genes make evolutionary leaps?, Science, 213, 634-636.

25. Mims, C.A. (1981). Vertical transmission of viruses, Microbiological Reviews, 45, 267-286.

26. Margulis, L. (1970). Origin of eukaryotic cells (Yale University Press, London).

27. Fine, P.E.M. (1975). Vectors and vertical transmission: An epidemiologic perspective, Annals New York Academy of Sciences, 266, 173-194.

28. Redaksioneel. (1978). Vertical transmission, The Lancet, March 18, 592-593.

29. Steele, E.J. (1980). Somatic selection and adaptive evolution: On the inheritance of acquired characters (Williams and Wallace, Toronto/Croom Helm, London).

30. Gorczynski, R.M. \& Steele, E.J. (1980). Inheritance of acquired immunological tolerance to foreign histocompatibility antigens in mice, Proceedings of the National Academy of Science, USA, 77, 2871-2875.

31. Gorczynski, R.M. \& Steele, E.J. (1981). Simultaneous yet independent inheritance of somatically acquired tolerance to two distinct $\mathrm{H}-2$ antigenic haplotype determinants in mice, Nature, 289 678-681.

32. News and Views. (1980). Lamarckist revival in immunology, Nature, 286, 837-838.

33. Redaksioneel. (1981). Shaking the evolutionary tree, The Lancet, April 11, 819-820.

34. Mitchison, N.A. (1980). Inheritance: The immunological challenge, Nature, 288, 306.

35. Brent, L., Rayfield, L.S., Chandler, P., Fierz, W., Medawar, P.B. \& Simpson, E. (1981). Supposed lamarckian inheritance of immunological tolerance, Nature, 290, 508-512.

36. Jones, K.W. (1981). Inherited tolerance?, Nature, 290, 286.

37. Preer, J.R. (1971). Extrachromosomal inheritance: hereditary simbionts, mitochondria, chloroplasts, Annual Review of Genetics, 5, 361-406.

38. Küntzel, H. \& Köchel, H.G. (1981). Evolution of RNA and origin of mitochondria, Nature, 293, 751-755.

39. Brent, L., Chandler, P., Fierz, W., Medawar, P. B., Rayfield, L.S. \& Simpson, E. (1982). Further studies on supposed lamarckian inheritance of immunological tolerance, Nature, 295, 242-244.

40. Calos, M.P. \& Miller, J.H. (1980). Transposable Elements, Cell, 20, 579-595. 